\title{
Synthesis and Structural Characterization of Novel Thulium-Platinum Heterobimetallic Complex $\left\{(\mathrm{DMF})_{10} \operatorname{Tm}_{2}\left[\mathrm{Pt}(\mathrm{CN})_{4}\right]_{3}\right\}_{\infty}$
}

\author{
Sang Mock Lee, ${ }^{\dagger}$ Jiyeon Kim, Sang Hern Kim, ${ }^{\ddagger}$ Jang-Hoon Chung, and Sheldon G. Shore ${ }^{*}$ \\ ${ }^{\dagger}$ Materials Center, Samsung Achanced Institute of Technologn, Yongin, Gunggi f+6-71 2, Korea \\ Deparment of Chemistry and Wano Science and Engineering, Hyongi Lniversitw Iongin, Gymggi 49-728, Korea \\ E-mail: chungihamiu.ackr \\ ${ }^{\ddagger}$ Department of Applied Chemistry, Hanbat National Lniversity, Daejeon $305-719$ Korea \\ \$Department of Chemistry, The Ohio State Lniversity, Columbus, OH 43210, L.S.A. "E-mail: shore. Ia ostuedu \\ Received November 15, 2006
}

Key Words : Thulium-platimum heterobimetallic complex. One dimensional array. Bridging cyanide

Lanthanide-transition heterobimetallic complexes have been intensively investigated because they can be employed as precursors in preparation of various materials such as oxide fuel cells, ${ }^{1}$ electroceramic ${ }^{2}$ and fluorescent materials. ${ }^{3}$ chemical sensor materials ${ }^{4}$ and catalysts. ${ }^{5}$ Incorporation of different metal atoms into the heterometallic complex may be accomplished through the formation of metal-metal bonds, or bridging ligands. Direct metal bonds between transition metals and electropositive lanthanide metals are relatively rare $^{5}$ and the heterobimetallic complexes with bridging ligands should be more accessible. The cyano groups of $\left[\mathrm{M}(\mathrm{CN})_{+}\right]^{3-}$ can be used as bidentate ligands which bridge metal atoms. ${ }^{7.8}$ Therefore, the heterobimetallic complexes containing cyanide-bridged lanthanide-transition metal arrays have been of interest.

Recently, we reported the Tnl-Pd heterobinetallic complex $\left\{(\mathrm{DMF})_{10} \operatorname{Tm}_{2}\left[\mathrm{Pd}(\mathrm{CN})_{4}\right]_{3}\right\}_{\infty}{ }^{9}$ and have focused on the syntheses of a series of thulium-group VIII transition metal conplexes using bridging cyanide ligand. Here we describe the preparation and the structural characterization of a novel one dimensional array Tm(III)-Pt heterobimetallic complex of the type $\left\{(\mathrm{DMF})_{10} \mathrm{Tm}_{2}\left[\mathrm{Pt}(\mathrm{CN})_{4}\right]_{3}\right\}_{\infty}$ prepared quantitatively from the reaction of $\mathrm{TmCl}_{3}$ and $\mathrm{K}_{2} \mathrm{Pt}(\mathrm{CN})_{4}(2: 3$ molar ratio). In this complex, $\operatorname{Tm}(\mathrm{III})$ ions are bridged by the bidentate $\mathrm{Pt}(\mathrm{CN})_{4}{ }^{--}$anions.

\section{Experimental Section}

General procedures. All manipulations were carried out using a standard high vacuum line or in a drybox under an atmosphere of nitrogen. Dimethyl formanide (DMF; Aldrich) was stirred over pretreated $4 \AA$ molecular sieves for $4-5$ days. The DMF was distilled into a $1000 \mathrm{~mL}$ flask and then stored in the drybox. $\mathrm{TmCl}_{3}$ was purchased from Aldrich and used as received. $\mathrm{K}=\left[\mathrm{Pt}(\mathrm{CN})_{4}\right] 3 \mathrm{H}_{2} \mathrm{O}$ (Aldrich) was dried under vacuum at $200^{\circ} \mathrm{C}$ for $\mathrm{I} \mathrm{h}$ and stored in the drybox. Fouier transform Infrared spectra were recorded on a Mattson Polaris Fourier Transform Spectrometer with $2 \mathrm{~cm}^{-1}$ resolution. Samples were prepared in the drybox and analyzed as films placed between $\mathrm{KBr}$ plates in an airtight sample holder. Elemental analysis was performed by Galbraith
Laboratories. Inc.. Knoxville. TN.

$X$-ray structural characterization. Single crystal X-ray diffraction data were collected on an Enraf-Nonius KappaCCD diffraction sy stem. which employs graphite monochromated Mo $\mathrm{K} \alpha$ radiation $(\lambda=0.71073 \AA$ ). A single crystal of $\left\{(\mathrm{DMF})_{10} \mathrm{Tm}_{2}\left[\mathrm{Pt}(\mathrm{CN})_{4}\right]_{3}\right\}_{*}$ was mounted on the tip of a glass fiber coated with Fomblin oil (pentafluoropolyether). Unit cell parameters were obtained by indexing the peaks in the first 10 frames and refuned employing the whole data set. Data integration was carried out for Lorentz and polarization effects using the Denzo-SMN package (Nonius BV. 1999). ${ }^{10}$ The absorption corrections were applied using the SORTAV program ${ }^{11}$ provided by MaXus software." ${ }^{13}$ The structure was solved by direct methods and refined using SHELXL-97 (difference electron density calculations and full matrix least-squares refinements) structure solution package. ${ }^{12}$

Preparation of $\left\{(\mathbf{D M F})_{10} \mathrm{Tm}_{2}\left[\mathbf{P t}(\mathbf{C N})_{4}\right]_{3}\right\}_{\infty}$ In a drybox. $275.3 \mathrm{mg}(1.0 \mathrm{mmol})$ of $\mathrm{TmCl}_{3}$ was dissolved in dry DMF in a $50 \mathrm{~mL}$ flask equipped with a Kontes Teflon stopcock and a magnetic stirring bar. To this solution was added $577.5 \mathrm{mg}$ $(2.0 \mathrm{mmol})$ of $\mathrm{K}_{2} \mathrm{Pt}(\mathrm{CN})_{4}$. After all reactants were dissolved in DMF. the mixture was stirred at room temperature for 5 days. During the process the solution turned cloudy due to the formation of $\mathrm{KCl}$. The precipitate was removed by filtration. and the yellow filtrate was reduced in volume for crystallization. X-ray quality single crystals fomed during dynamic vacuum in a day. Yield: nearly quantitative. IR (KBr, $v_{\mathrm{C}} ; \mathrm{cm}^{-1}$ ) 2184 (s). 2167 (s). 2139 (s), 2025 (w); Anal. Calcd for $\mathrm{C}_{42} \mathrm{H}_{70} \mathrm{~N}_{22} \mathrm{O}_{10} \mathrm{Pt}_{3} \mathrm{Tm}_{2}$ : C. 25.66: $\mathrm{H}, 3.59: \mathrm{N}$, 15.67. Found: C, 22.92: H, 3.10; N, 15.14

\section{Results and Discussion}

The metathesis reaction of $2: 3$ molar ratio of $\mathrm{TmCl}_{3}$ with $\mathrm{K}_{2} \mathrm{Pt}(\mathrm{CN})_{+}$in $\mathrm{DMF}$ produces one dimensional array of hetero-bimetallic complex of the general formula $\left\{(\mathrm{DMF})_{10} \mathrm{Tm}_{2}\left[\mathrm{Pt}(\mathrm{CN})_{4}\right]_{3}\right\} \times$ at room temperature (eq. $\left.\mathrm{l}\right)$.

$$
\begin{aligned}
& 2 \mathrm{TmCl}_{3}+3 \mathrm{~K}_{2} \mathrm{Pt}(\mathrm{CN})_{4} \stackrel{\mathrm{DNFF}}{\longrightarrow} \\
& \left.\quad(\mathrm{DMF})_{10} \operatorname{Tm}_{2}\left[\mathrm{Pt}(\mathrm{CN})_{4}\right]_{3}\right\}_{\infty}+6 \mathrm{KCl}
\end{aligned}
$$


Long reaction time of 5 days was employed to ensure complete removal of chloride as $\mathrm{KCl}$. The low solubility of $\mathrm{TmCl}_{3}$ in DMF also contributed to the long reaction time in the synthesis of the complex. The required long metathesis reaction time was in part due to the stability of the innersphere coordination complex. ${ }^{1+}$

Crystallographic data and selected bond distances and angles are listed in Table 1 and 2, respectively. The crystal structure shows the general formula $\left\{(\mathrm{DMF})_{10} \operatorname{Tn}_{2}\left[\mathrm{Pt}(\mathrm{CN})_{4}\right]_{3}\right\}_{\infty}$ with one dimensional array. This structure is consistent with Tm-Pd system. ${ }^{9}$ The repeating unit of the complex in Scheme 1 is translated only along the crystallographic a axis of the lattice. The structure consists of two parallel running zigzag chains that are inverted from each other. They are generated by two $\mathrm{Pt}(\mathrm{CN})^{4-}$ ions bridging $\mathrm{Tm}$ (III) ions in cis fashion. The chains are linked by a series of $\operatorname{Pt}(\mathrm{CN}) 4^{3-}$ ions bridging the $\mathrm{Tm}$ atoms in a trans fashion. The $\mathrm{Tm}$ (III) ions are bound to three $\mathrm{N}$ atoms of the bridging cyanides and five $\mathrm{O}$ atoms of DMF molecules. respectively. resulting in slightly distorted square antiprism. Two of the coordinated $\mathrm{N}$ atoms share an edge of one of the bases of the antiprism. while the third $\mathrm{N}$ atom occupies a comer of the other base opposite the shared edge. Average $\mathrm{Tm}-\mathrm{N}$ and $\mathrm{Tm}-\mathrm{O}$ bond distances are 2.448 and $2.312 \AA$ respectively. These average distances are comparable to those observed in $\mathrm{Tm}-\mathrm{Pd}$ and other lanthanide metal sy'stem., The coordination geometry around the platinum atom is approximately square planar. The widest C-Pt-C bond angle is $92.40(12)$ (C18$\mathrm{Pt} 2-\mathrm{C} 21)$ that bridges in a cis fashion to two sterically crowded thulium atoms. To bridge these two thulium atoms. the C18-Pt2-C21 is opened and thus this affects the linearity of the $\mathrm{M}-\mathrm{CN}$ bond ranging from $155.7(2)$ to $168.9(2)^{\circ}$. This is most likely due to steric crowding around the Tm(III)

Table 1. Crystallographic Data for $\left.(\mathrm{DMF})_{10} \operatorname{Tm}_{2}\left[\mathrm{Pt}(\mathrm{CN})_{4}\right]_{3}\right\}_{\infty}$

\begin{tabular}{|c|c|}
\hline empirical formula & $\mathrm{C}_{+2} \mathrm{H}_{70} \mathrm{~N}_{22} \mathrm{O}_{10} \mathrm{Pt}_{2} \mathrm{Tm}_{2}$ \\
\hline tw & 1966.33 \\
\hline space group & $\mathrm{PI}$ \\
\hline$a, A$ & $9.183(1)$ \\
\hline $\mathrm{b}, \mathrm{A}$ & $11.703(1)$ \\
\hline$c, A$ & $16.184(1)$ \\
\hline$\alpha$ deg & $79.858(3)$ \\
\hline$\beta, \operatorname{deg}$ & $74.818(3)$ \\
\hline$y$ deg & $80.877(5)$ \\
\hline $\mathrm{V}, \mathrm{A}^{\frac{5}{3}}$ & $1640.7(2)$ \\
\hline Z & 1 \\
\hline$\rho\left(\right.$ calcd) $m g / \mathrm{m}^{2}$ & 1.990 \\
\hline $\mathrm{T}, \mathrm{K}$ & $230(2)$ \\
\hline$\lambda, \hat{A}$ & $\operatorname{Mo~} \mathrm{K} \alpha(0.71073)$ \\
\hline$\theta$ range (deg) & $2.06 \cdot 27.49$ \\
\hline$h k l$ ranges & $-1111,-1515,-2121$ \\
\hline Reflections collected & 41377 \\
\hline Independent reflections & 7515 \\
\hline$H, \mathrm{~mm}^{-1}$ & 9.111 \\
\hline GOF & 1.088 \\
\hline$R_{1}[\mathrm{I}>2 \sigma(\mathrm{I})]^{a}$ & 0.0195 \\
\hline$w k_{2}$ (all data $)^{b}$ & 0.0427 \\
\hline
\end{tabular}

Table 2. Selected Bond Distances $(\AA)$ and Angles (deg)

\begin{tabular}{|c|c|}
\hline \multicolumn{2}{|c|}{ Bond Distances } \\
\hline $\operatorname{Tm}-\mathrm{O}(1) 2.352(2)$ & $\operatorname{Tm}-\mathrm{O}(2) 2.311(2)$ \\
\hline $\mathrm{Tm}-\mathrm{O}(3) 2.288(2)$ & $\operatorname{Tm}-O(4) 2.283(3)$ \\
\hline $\mathrm{Tm}-\mathrm{O}(5) 2.324(2)$ & $\operatorname{Tm}-\mathrm{N}(6) 2.413(3)$ \\
\hline Tm-N(8) $2.465(3)$ & $\mathrm{Tm}-\mathrm{N}(11) \neq 22.465(3)$ \\
\hline Pt(́) 1$)-C(16) 1.985(3)$ & $\mathrm{Ptt}(1)-\mathrm{C}(17) 1.991(4)$ \\
\hline Pt(2)-C(18) $1.988(3)$ & Pt( 2$)-C(19) 1.990(3)$ \\
\hline$P t(2)-C(20) 2.002(3)$ & Pt( 2$)-C(21) 1.996(3)$ \\
\hline$N(6)-C(16) 1.145(4)$ & $N(7)-C(17) 1.138(4)$ \\
\hline$N(8)-C(18) 1.146(4)$ & $N(9)-C(19) 1.1+1(4)$ \\
\hline $\mathrm{N}(10)-\mathrm{C}(20) 1.139(4)$ & $N(11)-C(21) 1.148(4)$ \\
\hline \multicolumn{2}{|c|}{ Bond Angles } \\
\hline $\mathrm{C}(17)-\mathrm{Pt}(1)-\mathrm{C}(17)+\mathrm{H} 1$ & 180.0 \\
\hline $\mathrm{C}(17)-\mathrm{Pt}(1)-\mathrm{C}(16)+1$ & $89.41(13)$ \\
\hline $\mathrm{C}(17) \# 1-\mathrm{Pt}(1)-\mathrm{C}(16) \# \mathrm{l}$ & $90.59(13)$ \\
\hline$C(17)-P t(1)-C(16)$ & $90.59(13)$ \\
\hline $\mathrm{C}(17) \# 1-\mathrm{Pt}(1)-\mathrm{C}(16)$ & $89.41(13)$ \\
\hline $\mathrm{C}(16) \# 1-\mathrm{Pt}(1)-\mathrm{C}(16)$ & $180.0(15)$ \\
\hline$C(18)-\operatorname{Pt}(2)-C(19)$ & $89.18(13)$ \\
\hline$C(18)-\operatorname{Pt}(2)-C(20)$ & $177.07(13)$ \\
\hline$C(19)-P t(2)-C(20)$ & $88.75(14)$ \\
\hline $\mathrm{C}(18)-\mathrm{Pt}(2)-\mathrm{C}(2 \mathrm{l})$ & $92.40(12)$ \\
\hline$C(19)-P t(2)-C(21)$ & $177.45(13)$ \\
\hline$C(20)-P t(2)-C(21)$ & $89.74(13)$ \\
\hline$C(16)-N(6)-T m$ & $165.1(3)$ \\
\hline $\mathrm{C}(18)-\mathrm{N}(8)-\mathrm{Tm}$ & $168.9(2)$ \\
\hline $\mathrm{C}(21)-\mathrm{N}(1 \mathrm{l})-\mathrm{Tm} \# 3$ & $155.7(2)$ \\
\hline
\end{tabular}

Symmetr: transfonmations used to generate equivalent atoms: $+\mathrm{l}-\mathrm{x} .-\mathrm{x}$; $-z-1$ \& $\mathrm{x}-1 . \mathrm{y}, \mathrm{z}+\mathrm{x}-1, \mathrm{y}, \mathrm{z}$

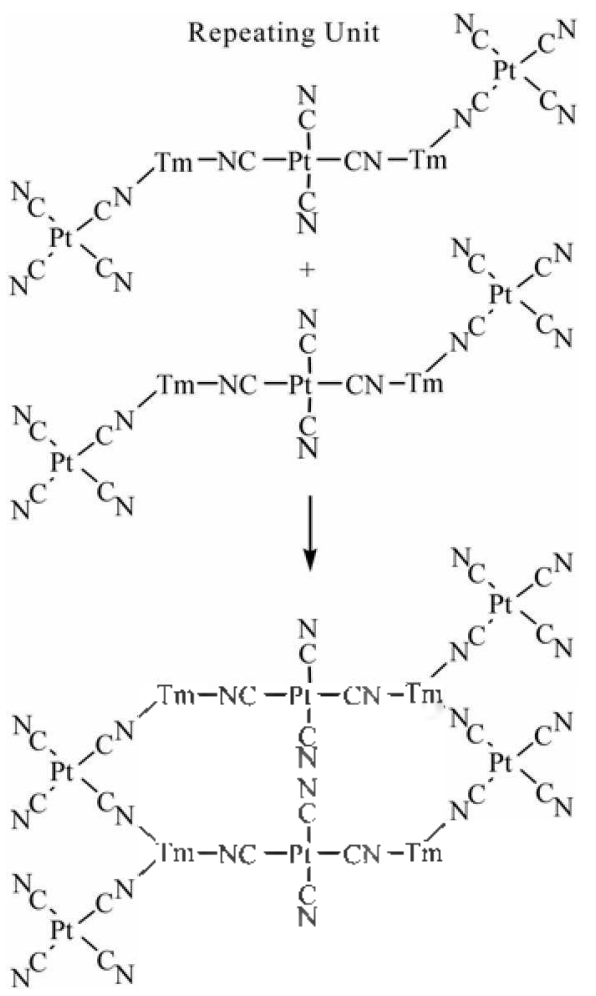

Scheme 1 


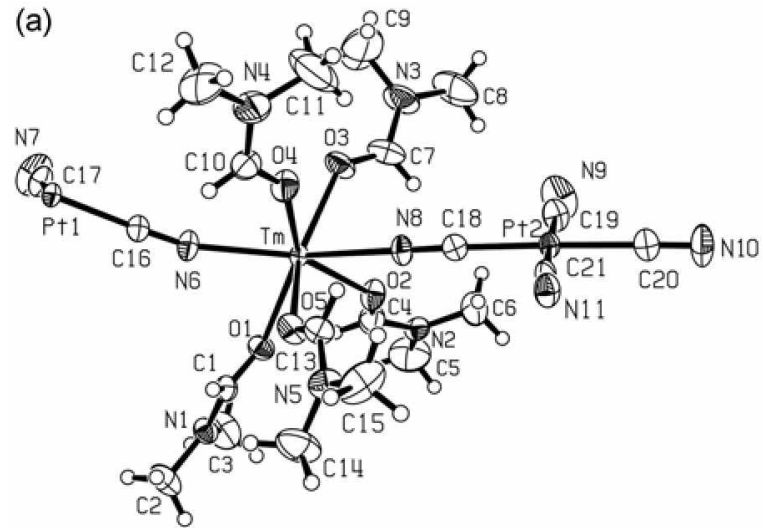

(b)

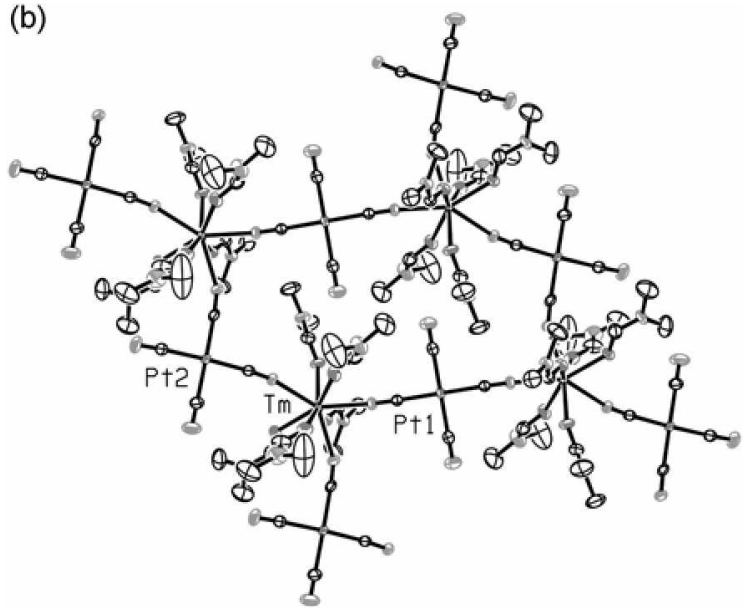

Figure 1. One dimensional structure ( $50 \%$ thennal ellipsoids) of $\left\{(\mathrm{DMF})_{10} \operatorname{Tm}_{2}\left[\mathrm{Pt}(\mathrm{CN})_{+}\right]_{3}\right\}_{2}$ (a) Coordination geometry around thulium atom. (b) A portion of one dimensional array.

cation.

The experimental section lists the observed infrared absorption frequencies for the complex. Array's $(\mathrm{DMF})]$ io$\left.\mathrm{Tm}_{2}\left[\mathrm{Pt}(\mathrm{CN})_{4}\right]_{3}\right\}_{*}$ and Tm-Pd system complex $\left\{(\mathrm{DMF})_{10}\right.$ $\left.\mathrm{T} \mathrm{m}_{2}\left[\mathrm{Pd}(\mathrm{CN})_{4}\right]_{3}\right\}$ display sinilar $\mathrm{CN}$ stretching patterns in their spectra of Figure 2. Cyanide stretching bands at higher



Figure 2. Infrared spectra of complex $\left.\left.1(\text { DMF })_{10} \operatorname{Tm}_{2}[\mathrm{PticN})_{4}\right]_{3}\right\}:=$ and complex $2\left[(\mathrm{DMF})_{10} \operatorname{Tm}_{2}\left[\mathrm{Pd}(\mathrm{CN})_{4}\right]_{3}\right\} \ldots$ frequencies than the stretching modes of $\mathrm{K}_{2}\left[\mathrm{Pt}(\mathrm{CN})_{4}\right] \cdot 3 \mathrm{H}_{2} \mathrm{O}$ $\left(2134 \mathrm{~cm}^{-1}\right)^{16}$ are assigned to bridging cyanide ligands. Typically bridging $\mathrm{CN}$ ligands have higher stretching frequencies than the tenminal CN ligands. ${ }^{17}$ The band occurs at around $2134 \mathrm{~cm}^{-1}$ is assigned to teminal cyanide ligands because their location in the cyanide stretching region compares with the absorptions observed for the nonbridging cyanide ligands in $\mathrm{K}_{2}\left[\mathrm{Pt}(\mathrm{CN})_{4}\right] \cdot 3 \mathrm{H}_{2} \mathrm{O}$.

Supplementary material. Cry stallographic data for structural analysis have been deposited with the Cambridge Crystallographic Data Center (CCDC No. 283317). Copy of this infonmation may be obtained free of charge from The Director. C.DC. 12 Union Road. Cambridge CB2 1EZ. UK (Fax: +44-1223-336033: e-mail depositaccdc.cam.ac. uk or www: htp. num:ccdc.com.ac.uk).

Acknowledgement. We thank Dr. Judith Gallucci in the Department of Chemistry of The Ohio State University for providing the crystal structure results.

\section{References}

1. Minh. N. Q.J.An. Ceram. Soc. 1993. 76. 563

2. (a) Shuk. P.: Vecher. A.: Kharton. V.: Tichonova. L.: Wiemhter. H. D; Guth, U.; Gpel, W. Sens. Actuators, B 1993, 16. 401. (b) Sadaoka. Y.: Traversa. E: Sakamoto. M. J. Hater: Chem 1996. $6(8), 1355$

3. Sakamoto. M.: Matsuki, K: Ohsumi. R:; Nakayama, Y.: Matsumoto, A.: Okawa. Y. Bull. Chem. Soc. Jpn. 1992. 65.2278.

4. (a) Matuura. Y.: Matsushima. S.: Sakamoto. M.: Sadaoka. Y. J. Mater. Chem. 1993. 3(7). 767. (b) Traversa. E.: Matsushima. S.: Okada. G.: Sadaoka. Y.: Sakai. Y.: Watanabe, K. Sens. Actuators. $B$ 1995, 25.661

5. (a) Imamura. H.: Miura, Y: Fujita. K.: Sakata Y: Tsuchiya S. $d$. Mol. Catal A 1999. 140.81. (b) Inamura. H.: Igawa. K.: Sakata. Y.: Tsuchiya. S. Bull Chent Sox. Jnn. 1996. 69.325.

6. Beletshaya. I. P.: Voskoboynikov. A. Z.: Chuklanova. E. B.: Kirillova, N. I: Shestakova, A. K.; Harshına. I. N.: Gusev, A. I.; Magomedov. G. K.I. J. Am Chem. Soc. 1993. 115, 3156.

7. Deng. H.: Chun, S.; Florian, P: Grandinetti. P. J.: Shore. S. G. Inorg. Chent 1996. 35.3891

8. (a) Knoeppel. D. W: Shore. S. G. Inorg Chem. 1996. 35. 1747 (b) Knoeppel. D. W.: Shore. S. G. Inorg. Chem. 1996. 35.5328

9. Chung. J.-H. Kim, S. H. Bull. Koman Chem. Soc. 2005, 26. 2075

10. Otwinowski. Z; Minor, W. In Methods in Enzymology: Carter, C. W. Ir. Sweet. K. M. Eds.: Academic Press. New York. 1997: vol. $276(\mathrm{~A})$. p 307.

11. (a) Blessing. R. H. Acta Crystallogr. Sect. A 1995. 51. 33. (b) Blessing. R. H. J. Appl. Chstallogr. 1997.30.421

12. Mackay. S.: Gılmore. C. J.: Edwards, C.: Tremayne, M.: Stuart, N.; Shankland, K. Haliss A Computer Program for the Solution and Refnement of Crystal Structures from Diffraction Data: University of Glasgow: Scotland: Nonius BV: Deltt. The Netherlands and Mac-Science Co. Ltd.: Yohohama. Tapan. 1998.

13. Sheldrick. G. M. SHELIZ-97: A Sinthetwe Solution and Refinenent Program: University of Gottingen: Germany, 1998.

14. Ishiguro, S.: Takahashı. R. Inorg. Chem. 1991, 30, 1854.

15. Knoeppel. D. W. Liu, J; Meyers. E. A.; Shore, S. G. Ihorg Chem 1998. 17.4828 .

16. Kubas. G. T.: Jones. L. H. Inorg. Chent 1974. 13.2186.

17. Nakamodo. K. Infrared and Raman Spectra of horgatic and Coordination Compounds. Part B. 5th ed; Wiley and Sons: New York. 1997: pp 105-113 and reterences therem. 